\title{
A Case of Language or Dialect Endangerment: Reviving Igbomina Through the Mass Media
}

\author{
Adebukunola A. Atolagbe, Ph.D. \\ Lagos State University, Lagos, Nigeria
}

\begin{abstract}
This paper discusses an attempt to revive and rescue Igbomina, a dialect of Yoruba, from the language shift process evident in many mother tongues spoken in Nigeria. Igbomina is spoken in two local governments in Kwara state, one local government each in Osun and Ekiti states of Nigeria. Two episodes each of a 30 minute programme "Omo Igbomina" on Radio Lagos were critically analyzed to find out if the goals of reviving Igbomina and preventing it from language shift towards the standard Oyo dialect, were being achieved. Many Igbomina youths, ages 15-30, who live outside Igbomina land, can hardly speak Igbomina nor understand it when spoken. A descriptive survey approach to investigate the impact of a peculiar and interesting programme, "Omo Igbomina", on this class of Igbominas was carried out with the following aims: (1) to discover if the intended audience are aware of the programme and if they are at all interested in such a programme; (2) to evaluate the sociolinguistic worth of the programme; (3) to discover the discourse and pragmatic features of the programme which are peculiarly Igbomina; and (4) to discover the positive effects of the programme or otherwise in revitalizing Igbomina dialect amongst indigenes of Igbomina land, as well as stopping the language shift process from Igbomina dialect to the standard Oyo dialect. A qualitative approach, employing purposive random sampling, with a sample size of 10 Igbomina youths was used. Questionnaires were administered to the informants. The questionnaire had both open-ended and close-ended questions and was tested for validity and reliability through a pilot study using three respondents. The results show that the programme is achieving its goals of encouraging language loyalty, preventing language shift and is a potential trigger of coordinate bilinguals - in English and Yoruba/Igbomina languages.
\end{abstract}

Keywords: language endangerment, Igbomina, mass media

\section{Introduction}

It can be said that Yoruba, which is the lingua franca in the southwest of Nigeria, has gained ascendancy over the various dialects that exist in the southwest region of Nigeria. Due to factors such as urbanization, improvement in communication networks, rural-urban migration, etc., many Nigerian languages or dialects of languages are greatly endangered. This is particularly so because of the multilingual nature of Nigeria, such that most Nigerians are either bilingual or multilingual. Indigenous languages come in contact with one another, as well as with English language which is the official language of the nation as well as the language of formal education, among its other functions. Among the younger generation, language shift is evident while many older speakers of indigenous Nigerian languages are becoming bilinguals (Oyetade, 2013).

Adebukunola A. Atolagbe, senior lecturer, Ph.D., Department of English, Lagos State University. 
The linguistic situation captured above, applies also to Igbomina dialect of Yoruba, which is the focus of this study. This mother tongue of the Igbomina people who are strategically distributed in the transitional region between the northern savannah and the rain forest zone of south-western region of Nigeria, is gradually dying in the hands of Igbomina youths. There is therefore a need to revive or revitalize this dialect of Yoruba. It is a Kwa language in the Niger-Kordofanian language family.

\begin{abstract}
Aims
There is a programme on Radio Lagos, which started off in February 2013 with the main purpose of reviving interest in the Igbomina language. This research therefore set out to achieve the following aims:

(1) To discover if the intended audience are aware of the programme and if they are at all interested in the programme;

(2) To evaluate the sociolinguistic worth of the programme;

(3) To discover the discourse and pragmatic features of the programme, which are particularly Igbomina;

(4) To discover the positive effects of the programme (or otherwise) in reviving Igbomina dialect among indigenes of Igbominaland, as well as stopping the language shift process from Igbomina dialect to the standard Oyo dialect.
\end{abstract}

\title{
Theoretical Base
}

Sociolinguistics and Pragmatics provided the theoretical base for this study. While Sociolinguistics exposes the inter-relationship between language and culture in a society: how both interact and influence each other (Hymes, 1964; Bello, 2008), Pragmatics deals with aspects of meaning from the perspective of "what did you mean by x?" Semantics, another field of language study that deals with meaning, however, does so from the perspective of "what does x mean?" (Leech, 1983, pp. 5-6). Insights from Pragmatics are brought to bear on the interpretation of the content of the radio programme analyzed in this paper. How context influences the derived implicatures in the two episodes of the programme analyzed viz-a-viz the understanding of the informants and the perlocutionary effects of various aspects of the speeches of the programme presenters is worthy of note (Adegbija, 1989; Mey, 2001; Akhimien, 2012). Thus, the sociolinguistic and pragmatic contents of the programme as perceived in the two episodes analysed, reveal an attempt by the presenters to revitalize Igbomina dialect of Yoruba among all Igbominas, irrespective of age.

\section{Methodology}

This paper discusses an attempt to revive and rescue Igbomina dialect from the language shift process evident in this dialect of Yoruba, as it is spoken today by many of the younger generation of Igbomina citizens. Two episodes of a 30 minute programme "Omo Igbomina" on Radio Lagos were played back to selected Igbomina youths and critically analysed to find out if the goals of reviving Igbomina dialect and preventing it from language shift towards the standard Oyo dialect, were being achieved.

A descriptive survey approach was adopted. The focus was qualitative rather than quantitative. A sample size of 10 Igbomina youths (ages 13-30) who had lived or stayed in Lagos before, irrespective of the present state of abode, and from different parents, provided the data used for the study. Questionnaires were administered to the informants after exposure to the programme. The questionnaire had both close-ended and open-ended questions and was tested for reliability and validity through a pilot study utilizing the first three respondents. 
Answers from the questionnaire were extracted, analyzed, and are presented below.

\section{Data Presentation and Analysis}

\section{Biodata of Informants}

Table 1

Gender

\begin{tabular}{lll}
\hline Sex & No. & $\%$ \\
\hline Male & 5 & 50 \\
Female & 5 & 50 \\
Total & 10 & 100 \\
\hline
\end{tabular}

Table 2

Age

\begin{tabular}{lll}
\hline Age & No. & $\%$ \\
\hline $13-15$ & $1(1$ female $)$ & 10 \\
$16-20$ & $4(2$ males, 2 females $)$ & 40 \\
$21-25$ & $1(1$ male $)$ & 10 \\
$26-30$ & $4(2$ males, 2 females $)$ & 40 \\
Total & 10 & 100 \\
\hline
\end{tabular}

Table 3

Place of Residence

\begin{tabular}{lll}
\hline State & No. & $\%$ \\
\hline Lagos & 1 (1 female $)$ & 10 \\
Ogun & $3(2$ males, 1 female $)$ & 30 \\
Oyo & 1 (1 female $)$ & 10 \\
Others & $5(3$ males, 2 females $)$ & 50 \\
\hline
\end{tabular}

From the Tables 1-3 above, we discover that five were males while five were females. Also, one was 13 years old, four were between the ages of 16-20, one was between 21-25 years old and four informants were 26-30. With regard to place of residence, one resides in Lagos State, three reside in Ogun Sate (but actually the border towns to Lagos-Ota, Alagbole) and one lives in Oyo State. Five live outside Lagos (schooling or participating in the national youth service corps scheme), namely, one person in Akwa Ibom state, one person in Kwara State, one in Delta State, one in Abuja FCT and one in the United States of America.

\section{Language Use by Informants}

Table 4

Language(s) Well Understood

\begin{tabular}{lll}
\hline Language & No. & $\%$ \\
\hline Yoruba & $10(5$ males, 5 females $)$ & 100 \\
English & 9 (all excluding 1 female $)$ & 90 \\
Igbomina dialect & 9 (all excluding 1 female $)$ & 90 \\
Others (French/Hausa/Ibibio) & $1 / 1 / 1$ (1 male for each) & 10 \\
\hline
\end{tabular}


Table 5

Language(s) Spoken Well

\begin{tabular}{lll}
\hline Language & No. & $\%$ \\
\hline Yoruba & $6(5$ males, 1 female $)$ & 60 \\
English & 8 (4 males, 4 females $)$ & 80 \\
Igbomina dialect & 4 (4 males) & 40 \\
Others (Hausa) & 1 (1 male) & 10 \\
\hline
\end{tabular}

\section{Reviving Igbomina Dialect}

The Tables 6-11 below show the degree of awareness of the programme on the part of the informants and their opinion of the programme. Thus we can assess if the programme is achieving its goals or not.

Table 6

Awareness of Radio Programme

\begin{tabular}{lll}
\hline Status & No. & $\%$ \\
\hline Aware of programme & 7 (5 males, 2 females $)$ & 70 \\
Not aware of programme & 3 (3 females, 0 male $)$ & 30 \\
\hline
\end{tabular}

Table 7

Subject Has Listened to Programme Before

\begin{tabular}{lll}
\hline Status & No. & $\%$ \\
\hline Have listened to it before & 6 (4 males, 2 females $)$ & 60 \\
Have just listened to it & 4 (3 females, 1 male $)$ & 40 \\
\hline
\end{tabular}

Table 8

Liking for the Programme

\begin{tabular}{lll}
\hline Status & No. & $\%$ \\
\hline Will like to keep listening & 7 (5 males, 2 females) & 70 \\
May like to keep listening & 3 (3 females, 0 male) & 30 \\
Not likely to keep listening & 0 & 0 \\
Will not keep listening & 0 & 0 \\
\hline
\end{tabular}

Table 9

Reasons for Liking/Disliking Programme

\begin{tabular}{lll}
\hline Status & No. & $\%$ \\
\hline Really enjoyed it & 5 (4 males, 1 female $)$ & 50 \\
Well, it is okay & $4(3$ females, 1 male $)$ & 40 \\
Could not follow it & 1 (1 female $)$ & 10 \\
Not interested & 0 & 0 \\
\hline
\end{tabular}

Table 10

It Is Good Enough to Revive Igbomina

\begin{tabular}{lll}
\hline Status & No. & $\%$ \\
\hline Yes & $10(5$ males, 5 females $)$ & 100 \\
Maybe & 0 & 0 \\
Not likely & 0 & 0 \\
No & 0 & 0 \\
\hline
\end{tabular}


Table 11

Closeness of Igbomina to Standard Yoruba

\begin{tabular}{lll}
\hline Status & No. & $\%$ \\
\hline No difference between them & 0 & 0 \\
Very close & $8(5$ males, 3 females $)$ & 80 \\
Just a little similar & 0 & 0 \\
Totally different & $2(2$ females, 0 male $)$ & 20 \\
\hline
\end{tabular}

\section{Discussion}

From the tables above, we make the following observations:

Many of the respondents exhibited a high degree of language loyalty, even when they had not been aware of the programme prior to this research work; this was particularly so with all the $50 \%$ male informants and $20 \%$ of the female informants who were older (aged 26-30).

The sociolinguistic content of the radio programme reflected the following:

The programme always began with a created Sign-in Igbomina music, "rara", eulogies, "oriki”, praise singing, etc. Sponsors of the programme were praised or commended intermittently throughout the programme, e.g., FIJIK. During the short phone-in segment, questions on Igbomina personalities, traits, terms, expressions, etc., were asked by the two presenters - a male and a female, and answered by the callers. Also, businesses and addresses of sponsors were advertized and the presenters solicited for more sponsors as they encouraged Igbomina listeners to be proud of their language, culture and heritage.

The pragmatic content of the radio programme reflected the following:

Both presenters always spoke heartily, observing and sometimes breaking rules of conversation/discourse, e.g., turn taking, politeness and conversation principles. Listeners were entertained in different ways through jokes, witty sayings, proverbs, inuendos, etc. Both Igbomina and non Igbomina callers were entertained on the programme. Igbominas of all faiths and from all regions called into the programme, especially the elderly and middle-aged. There was a pervading underlying pragmatic use of tone-register tones with approximately pragmatic value (Adewale, 2013; Salem, 2013). Code mixing English with Igbomina occurred sometimes but not too often. Like many others have argued, this feature of code-mixing, has been a significant part of English usage in Nigeria today (Abdullahi-Idiagbon, 2007; Atolagbe, 2012), e.g., question number 1, popsi/momsi, yes sir, valentine, hello/hallo, Passo gee boy, etc., occurred in the discourse of the presenters.

Instances of derived conversational implicatures were observed in the discourse interaction between the callers and presenters, jokes were cracked and a lot of fun activity took place. The presenters were very polite and exchanged both greetings and a lot of pleasantries with callers, a characteristic feature of the Yorubas and their language (Adegbija, 1989, 1993, 1994; Adegbite, 2007).

Effects of the Programme on the informants include the following:

Many of the respondents aired their views as follows:

(1) Highly educative and informative programme, e.g., learnt of Osun, Ekiti, Kwara Igbominas;

(2) It creates awareness about the language/dialect and shows unique expressions, phrases, exclamations, etc.;

(3) Helps to remember home and relate as one family;

(4) Awakens interest in the dialect/culture; 
(5) A very traditional and entertaining programme;

(6) It helps to understand the general personality of the Igbomina people such as being respectful and a fun-loving people.

However, it was obvious that more elderly people called in and the programme was not popular among the younger generation. Attracting younger callers could be achieved by getting more radio or television stations in the southwest, particularly those with youthful programmes, or even African Magic and Yoruba stations, airing this and similar programmes. Also, topics that interest the youths should be included, e.g., telecoms, education/admission issues, arts and fashion, more innovative programmes, etc.

We agree with Arua and Ekpenyong (2014) who claim that among the minority communities, language revitalization is achievable when its status significantly permeates new domains, develops into a language of the educated class, and adopts new societal values. Hence, we would be strengthening minority languages/dialects by developing plurilingual citizens in multilingual societies, according to Waya (2014).

\section{Conclusion}

From the foregoing, we conclude by stating that as more youths get interested in this kind of programme, we will produce coordinate bilinguals in Yoruba (the standard Oyo variety or not) and English, that is, those who understand Igbomina and English, or other pairs of languages, especially in future generations, encourage language loyalty, prevent language shift and language endangerment of our mother tongues, while English continues to play the major roles foisted on it in multilingual Nigeria. Other indigenous languages can thus take a cue from the findings of this research work. These assertions are premised on the fact that in as much as African linguists champion the cause of empowering indigenous languages in every respect, the English language which has apparently come to stay in multilingual Nigeria, can continue to play its diverse roles in the official and educational domains.

Also, just as in South Africa, the Mass media would also be playing a major role in empowering indigenous, albeit endangered Nigerian languages/dialects (Mmusi, 2014). Choosing an indigenous language as national language is indeed a political question and not a linguistic question, hence linguists have not been able to arrive at a common position on this knotty issue.

\section{References}

Abdullahi-Idiagbon, S. M. S. (2007). Code-mixing with English and the future of the Nigerian languages. In I. Udofot (Ed.), Journal of Nigeria English Studies Association, 3(1), 35-46. Ikot Ekpene: Devconsort Publishers.

Adegbija, E. E. (1989). A comparative study of politeness phenomena in Nigerian English, Yoruba and Ogori. Multilingual, 8(1), 57-80. Germany: Mouton de Gruter.

Adegbija, E. E. (1993). Greeting norms in Nigeria and Germany: Their place in intercultural understanding and misunderstanding. In Duisburg: L.A.U.D. Duisburg: Linguistic Agency University of Duisburg.

Adegbija, E. E. (1994). Language attitude in Sub-Saharan Africa: A socio-linguistic overview. Clevedon Avon: Multilingual Matters.

Adegbite, W. (2007). Towards standardizing English language usage in Nigeria: A case study of expression of Yoruba greetings in English. Journal of Nigerian English Studies Association, 3(1), 81-94. Ikot Ekpene: Devconsort Publishers.

Adegbite, W. (2009). The psycholinguistics of English language in Nigeria. Ibadan: Kraft Books Limited.

Adewale, H. O. (2013). Optimality theory and tone in Igbomina. Paper presented at The 50th West African Languages Congress (WALC) and The 26th Conference of the Linguistic Association of Nigeria (CLAN), University of Ibadan, Nigeria.

Akhimien, P. E. (2012). Language as action: An introduction to the speech act theory. Ibadan: Free Enterprise Publishers. 
Atolagbe, A. A. (2012). Semiotics and language interlarding in Yoruba traditional wedding bilingual discourse. International Journal of English and Literature, 3(7), 158-165.

Bello, O. R. (2008). A sociolinguistic description of condolences among Yoruba English speakers in Southwestern Nigeria (p. 256) (An unpublished Ph.D. thesis submitted to the University of Ibadan, Nigeria).

Hymes, D. (1964). Language in culture and society. New York: Harper and Row.

Leech, G. (1983). Principles of pragmatics. London and New York: Longman.

Mey, J. L. (2001). Pragmatics: An introduction (2nd ed.). Malden, USA and Oxford, UK: Blackwell Publishing.

Mmusi, S. (2014). Strategies for the empowerment of African languages: Successes and challenges facing South Africa. Unpublished paper presented at The 1st Linguistics and African Languages Conference (LALIC), Kwara State University, Nigeria.

Oyetade, S. (2013). Language shift from mother tongues towards Yoruba in Oke-Agbe, Ondo State: Causes and consequences. Unpublished paper presented at The 50th West African Languages Congress (WALC) and The 26th Conference of the Linguistic Association of Nigeria (CLAN), University of Ibadan, Nigeria.

Salem, O. E. (2013). Basic register tones: Pragmatics and identification. Paper presented at The 50th WALC and 26th CLAN, University of Ibadan, Nigeria.

Urua, E., \& Ekpenyong, M. (2014). African languages empowerment: The experience with non-major languages. Unpublished Paper presented at $L A L I C$, Kwara State University, Nigeria.

Waya, D. (2014). Developing plurilingual citizens in multilingual societies: Strengthening minority languages in Nigeria. Unpublished paper presented at $L A L I C$, Kwara State University, Nigeria. 